\title{
Nigella sativa oil: physico-chemical properties, authentication analysis and its antioxidant activity
}

\author{
1,2* Rohman, A., ${ }^{1}$ Lukitaningsih, E., ${ }^{3}$ Rafi, M., ${ }^{4}$ Nurrulhidayah, A.F. and ${ }^{5}$ Windarsih, A. \\ ${ }^{1}$ Department of Pharmaceutical Chemistry, Faculty of Pharmacy, Universitas Gadjah Mada, Yogyakarta \\ ${ }^{2}$ Institute of Halal Industry and Systems, Universitas Gadjah Mada, Yogyakarta 55281 Indonesia \\ ${ }^{3}$ Department of Chemistry, Faculty of Mathematics and Natural Sciences, IPB University, Jalan Tanjung \\ Kampus IPB Dramaga, Bogor 16680, Indonesia \\ ${ }^{4}$ International Institute for Halal Research and Training (INHART), International Islamic University \\ Malaysia, Gombak, 50728, Kuala Lumpur, Malaysia \\ ${ }^{5}$ Research Unit for Natural Products Technology (BPTBA), Indonesian Institute of Sciences (LIPI), \\ Yogyakarta, Indonesia
}

\author{
Article history: \\ Received: 5 March 2019 \\ Received in revised form: 6 \\ April 2019 \\ Accepted: 8 April 2019 \\ Available Online: 12 April \\ 2019
}

Keywords:

Nigella sativa oil,

Antioxidant,

Black cumin,

Physico-chemical properties, Authentication

\section{DOI:}

https://doi.org/10.26656/fr.2017.3(6).115

\begin{abstract}
Nigella sativa oil (NSO) is one of the high value oils in fats and oils industry due to its nutritional applications and its beneficial effects on human health. Several biological activities have been reported, especially antioxidant activities due to its active components, especially phenolics compounds. Some methods have been used for extraction of NSO from seeds to obtain high yield with excellent quality which includes solvent extraction, cold press, Soxhlet, and microwave assisted extraction. NSO commands a high price in the market, as a consequence, NSO is a target to be adulterated with cheaper oils such as corn and soybean oils. Indeed, the authentication analysis of NSO by determining several physico-chemical properties to determine the characteristics of NSO must be performed. This review highlighted some physico-chemical properties of NSO along with authentication of NSO from adulterants. The antioxidant activities of NSO were also highlighted in this review. Based on its activity as antioxidant, NSO is a good source to be used in nutraceutical and pharmaceutical products.
\end{abstract}

\section{Introduction}

For many centuries, herbal Medicinal plants have evolved as an interesting issue, to be used for preventing and curing several diseases, especially degenerative diseases such as diabetic and hypertension in different systems of folk medicines as well as indigenous medicine. Herbal medicines are interesting for researchers focusing on types of medicinal plants having medicinal properties, mechanism of action, potential, safety evaluation as well as toxicological studies. Among various medicinal plants, Nigella sativa has emerged as a miracle herb on the basis of history and religion (Ahmad et al., 2013). Nigella sativa (N. sativa) belong to Family Ranunculaceae is also known as Habbatus sauda, Habbet el Baraka', Al-Kammoon Al-Aswad', Shunez' and black cumin (Nurrulhidayah et al., 2011).

This plant is widely used in herbal medicines throughout the world, especially in Islamic countries such as the Middle East, Malaysia, and Indonesia. In the literacy of the Islamic community, $N$. sativa is taken into account as one of the most common plants used for healing or preventing of some diseases. Tibb-e-Nabwi or Prophetic Medicine has recommended using this plant on a regular basis. Prophetic hadith stated that black seed is the remedy for all diseases except death (Ahmad et al., 2013). Besides, this plant especially seeds and oils are also popular to be used in various traditional systems of herbal medicine such as Ayurveda and Siddha as well as Unani and Tibb (Sultana et al., 2015). The seeds and oils of $N$. sativa are also good food components to be used in the dietary systems as a spice and food preservative. Besides, both seeds and oils have been reported to have several biological activities including antioxidant, antimicrobial, antihypertensive, anticancer, antiinflammatory, diuretics, anti-diarrheal, appetite stimulant, analgesics, and for treatment of skin disorders, therefore seeds of $N$. sativa can be considered as functional food components. Nigella sativa oil (NSO) supplementation along with conservative management is safe in averting the progression of chronic kidney disease in stage 3 and 4 patients (Ansari et al., 2016). 
Nigella sativa oil (NSO) has a pleasant taste and a specific odor. In the fats and oils industry, NSO commanded a high price, 10-15 times more expensive than other edible oils such as palm oil, corn oil and soybean oil. This fact has attracted the unethical market players to mix or adulterate NSO with other low priced oils to gain economic profit. Therefore, the identification of NSO from any adulteration must be addressed to assure the authenticity of NSO (Rohman and Ariani, 2013). In this review, some physico-chemical methods have been highlighted including authentication studies of NSO.

\section{Methods}

During performing this review, we used several databases including Scopus, PubMed, and Google Scholar to identify and to download the abstracts, reports, and research papers related to physico-chemical properties, authentication, and antioxidant activities of Nigella sativa oil. The keywords used during searching of information was: (1) (characterization + Nigella sativa oil or characterization + black seed cumin oil); (1) (authentication or adulteration + Nigella sativa oil); (3) (antioxidant activities + Nigella sativa oil + in vitro or in vivo); (4) (nutritional aspects + Nigella sativa oil + human health) in the month of April-September 2018.

\section{Physico-chemical properties and chemical composition of Nigella sativa oil}

Nigella sativa oil (NSO) was typically obtained by non-polar solvent extraction and cold-press procedure. The oil contents in most Nigella seeds studied were typically $30-40 \%$, depending on environmental conditions such as water-stress, saline conditions, and temperatures (Khan, 1999; Cheikh-Rouhou et al., 2007). Gharby et al. (2015) have reported that the oil contents of Nigella seeds obtained from Morocco using hexane extraction and cold press-extraction yielded $37 \%$ and $27 \%$, respectively. Some physico-chemical parameters were also affected by techniques used for oil extraction. Khoddami et al. (2011) also compared the yields of NSO obtained by three different extracts. The highest yield was observed using Soxhlet $(37.33 \pm 0.15 \%)$, using petroleum ether as a solvent, over Modified Bligh-Dyer with a yield of $33.24 \pm 0.59 \%$ and hexane extraction with a yield of $31.76 \pm 0.64 \%$.

NSO obtained by two extraction methods (hexane extraction and cold press) have been compared in terms of Free fatty acids (as oleic \%), Iodine value ( $\mathrm{g}_{\text {of }} \mathrm{I}_{2} / 100$ g), $\mathrm{K} 232, \mathrm{~K} 270, \mathrm{PV}\left(\mathrm{MeqO}_{2} / \mathrm{kg}\right)$, and Refractive index at $20^{\circ} \mathrm{C}$. Kiralan et al. (2014) have compared some physicochemical properties of NSO extracted by three different methods (Soxhlet extraction using hexane, microwave extraction, and cold press). The values of corresponding these properties were compiled in Table 1.

Table 1. Physico-chemical properties and fatty acid composition of Nigella sativa oil.

\begin{tabular}{|c|c|c|c|}
\hline Physico-chemical properties & Cold-press & Hexane extraction & Microwave extraction \\
\hline $\begin{array}{l}\text { Free fatty acids (as oleic } \\
\text { acid } \% \text { ) }\end{array}$ & $\begin{array}{c}0.9 \pm 0.2^{\mathrm{a}} \\
(7.49 \pm 0.96)^{\mathrm{b}}\end{array}$ & $\begin{array}{c}2.3 \pm 0.5^{\mathrm{a}} \\
(9.28 \pm 0.63)^{\mathrm{b}}\end{array}$ & $(9.51 \pm 0.36)^{b}$ \\
\hline Iodine value $\left(\mathrm{g}\right.$ of $\left.\mathrm{I}_{2} / 100 \mathrm{~g}\right)$ & $128 \pm 2^{\mathrm{a}}$ & $126 \pm 4^{\mathrm{a}}$ & - \\
\hline $\mathrm{K}_{232}$ & $\begin{array}{l}1.585 \pm 0.008^{\mathrm{a}} \\
(3.71 \pm 0.12)^{\mathrm{b}}\end{array}$ & $\begin{array}{c}2.21 \pm 0.01^{\mathrm{a}} \\
(3.11 \pm 0.06)^{\mathrm{b}}\end{array}$ & $(0.58 \pm 0.05)^{\mathrm{b}}$ \\
\hline $\mathrm{K}_{270}$ & $\begin{array}{c}2.370 \pm 0.003^{\mathrm{a}} \\
(0.66 \pm 0.05)^{\mathrm{b}}\end{array}$ & $\begin{array}{c}2.771 \pm 0.009^{\mathrm{a}} \\
(0.66 \pm 0.06)^{\mathrm{b}}\end{array}$ & $(0.58 \pm 0.05)^{b}$ \\
\hline Peroxide value $\left(\mathrm{MeqO}_{2} / \mathrm{kg}\right)$ & $\begin{array}{c}3.4 \pm 0.5^{\mathrm{a}} \\
(31.32 \pm 0.74)^{\mathrm{b}}\end{array}$ & $\begin{array}{c}11.4 \pm 2.5^{\mathrm{a}} \\
(25.23 \pm 1.56)^{\mathrm{b}}\end{array}$ & $(21.45 \pm 0.79)^{b}$ \\
\hline Refractive index at $20^{\circ} \mathrm{C}$ & $\begin{array}{l}1.468 \pm 0.003^{\mathrm{a}} \\
(1.473 \pm 0.00)^{\mathrm{b}}\end{array}$ & $\begin{array}{l}1.473 \pm 0.002^{\mathrm{a}} \\
(1.471 \pm 0.00)^{\mathrm{b}}\end{array}$ & $1.471 \pm 0.00)^{\mathrm{b}}$ \\
\hline Fatty acids ${ }^{c}$ & Concentration $(\%)$ & & \\
\hline Miristic Acid (C 14:0) & $0.13-0.16$ & & \\
\hline Palmitic Acid (C 16:0) & $12.90-13.25$ & & \\
\hline Palmitoleic Acid C 16:1) & $0-0.60$ & & \\
\hline Margaric Acid (C 17:0) & 0.06 & & \\
\hline Heptadesenoic Acid (C 17:1) & $0.03-3.29$ & & \\
\hline Stearic Acid (C 18:0) & $2.56-2.80$ & & \\
\hline Oleic Acid (C 18:1) & $22.63-24.51$ & & \\
\hline Linoleic Acid (C 18:2) & $58.90-61.20$ & & \\
\hline Linolenic Acid (C 18:3) & $0.21-0.28$ & & \\
\hline Arashidic Acid (C 20:0) & $0.13-0.15$ & & \\
\hline Eicosenoic Acid (C 20:1) & $0.27-0.35$ & & \\
\hline Eicosadienoi c Acid (C 20:2) & $1.86-9.40$ & & \\
\hline Behenic Acid (C 22:0) & $0.50-1.30$ & & \\
\hline Docosenoic Acid (C 22:1) & $0.30-1.10$ & & \\
\hline
\end{tabular}

${ }^{a}$ Data taken from Garby et al. (2015); ${ }^{b}$ Data taken from Kiralan et al. (2014); ${ }^{\mathrm{c}}$ Data taken from Argon and Gokyer (2006). 
Table 2. Some bioactive lipid components present in Nigella sativa oil (NSO) with different extraction methods (Argon and Gokyer, 2006; Kiralan et al., 2014).

\begin{tabular}{lccc}
\hline \multirow{2}{*}{ Bioactive lipid components } & \multicolumn{3}{c}{ Extraction methods } \\
\cline { 2 - 4 } & Cold-press & Soxhlet extraction & Microwave extraction \\
\hline$\alpha$-tocopherol $(\mathrm{mg} / \mathrm{kg})$ & $7.30 \pm 0.46$ & $4.80 \pm 0.36$ & $5.33 \pm 0.12$ \\
$\beta$-tocopherol $(\mathrm{mg} / \mathrm{kg})$ & $15.47 \pm 0.29$ & $8.00 \pm 0.36$ & $7.80 \pm 0.17$ \\
$\gamma$-tocopherol $(\mathrm{mg} / \mathrm{kg})$ & $34.23 \pm 0.21$ & $9.57 \pm 0.51$ & $8.57 \pm 0.21$ \\
$\delta$-tocopherol $(\mathrm{mg} / \mathrm{kg})$ & $8.37 \pm 0.12$ & $1.80 \pm 0.10$ & $1.63 \pm 0.06$ \\
Campestrol $(\mathrm{mg} / \mathrm{kg})$ & $14.88 \pm 0.19$ & $13.47 \pm 0.43$ & $14.71 \pm 0.34$ \\
Stigmasterol $(\mathrm{mg} / \mathrm{kg})$ & $17.48 \pm 0.54$ & $17.49 \pm 0.43$ & $18.70 \pm 0.59$ \\
$\beta$-sitosterol $(\mathrm{mg} / \mathrm{kg})$ & $58.05 \pm 1.01$ & $57.49 \pm 0.82$ & $57.41 \pm 0.17$ \\
$\Delta^{5}$-Avenasterol $(\mathrm{mg} / \mathrm{kg})$ & $7.27 \pm 0.74$ & $8.80 \pm 0.23$ & $7.34 \pm 0.58$ \\
$\Delta^{7}$-Avenasterol $(\mathrm{mg} / \mathrm{kg})$ & $1.24 \pm 0.10$ & $1.14 \pm 0.26$ & $0.89 \pm 0.09$ \\
$\Delta^{7}$-Avenasterol $(\mathrm{mg} / \mathrm{kg})$ & $1.62 \pm 0.31$ & $1.28 \pm 0.25$ & $1.58 \pm 0.34$ \\
$p$-hydroxy benzoic acid $(\mu \mathrm{g} / \mathrm{g})$ & $1.50 \pm 0.00$ & $0.20 \pm 0.00$ & $0.20 \pm 0.00$ \\
Benzoic acid $(\mu \mathrm{g} / \mathrm{g})$ & $4.15 \pm 0.07$ & $2.15 \pm 0.07$ & $2.65 \pm 0.07$ \\
Cinnamic acid $(\mu \mathrm{gg} / \mathrm{g})$ & $0.03 \pm 0.00$ & $0.05 \pm 0.00$ & $0.06 \pm 0.00$ \\
Thymoquinone $(\mu \mathrm{g} / \mathrm{g})$ & $14.40 \pm 0.57$ & $5.65 \pm 0.07$ & $6.20 \pm 0.28$ \\
\hline
\end{tabular}

Linoleic and oleic acids are the main fatty acids composed NSO (Argon and Gokyer, 2016). Table 1 also compiled the fatty acid composition of NGO. NSO was characterized by high contents of PUFA (polyunsaturated fatty acids) and MUFA (monounsaturated fatty acids). MUFA have been reported to lower bad LDL (low-density lipoproteins) cholesterol and retain good HDL (high-density lipoproteins) cholesterol, which makes NSO as a good component to be used in the nutritional and pharmaceutical applications (Ramadan et al., 2010). Khoddami et al. (2011) reported that main triacylglycerols which composed NOS were LLL (19.90 $-20.60 \%)$, OLL (16.07-16.97\%) and PLL (12.40$18.51 \%)$. They also contained small quantities of POO and PPO.

Some active components are believed to be responsible for several biological activities such as tocopherols, carotenoid, and phenolics compounds and thymoquinone. Kiralan et al. (2014) have reported some lipid components in NSOs extracted by Soxhlet, microwave and press cold, and the results were compiled in Table 2. Compositional analysis of NSO using gas chromatography-mass spectrometry (GC-MS) contained $17.47 \%$ caryophyllene, $11.80 \%$ thymoquinone, $7.17 \%$ 1,4-cyclohexadiene, $3.5 \%$ longifolene, and $1.82 \%$ carvacrol (Mohammed et al., 2016). Some components 9 compounds) were also isolated and identified using GCMS from essential oils of NSO namely 2-methyl-5(1methyl ethyl)-bicyclo-hex-2-ene as a major component and alpha-pinene as a minor compound (Adamu et al., 2010). Ahmad et al. (2013) also reported that NSO extracted by steam distillation contained carvone, dlimonene and nigellone. However, studies reported that the composition of NSO varies with the geographical regions, where the plant is cultivated (D'Antuono et al., 2002; Cheikh-Rouhou et al., 2007).

\section{Authentication of Nigella sativa oil}

Using literature review in Scopus (www.scopus.com), only one method has been reported for authentication of NSO, namely Fourier transform infrared spectroscopy. Rohman and Ariani (2013) have used Fourier transform infrared (FTIR) spectroscopy in combination with partial least square regression (PLSR) was used for authentication of NSO mixed in binary systems with corn oil and soybean oil (NSO-CO and NSO-SO) as well as in ternary mixtures of NSO-CO-SO. Based on optimization for selecting the best calibration models in terms of highest coefficient of determination $\left(\mathrm{R}^{2}\right)$ and lowest errors in calibration and prediction, the second derivative of FTIR spectra at combined wavenumbers of $2977-3028 \mathrm{~cm}^{-1}, 1666-1739 \mathrm{~cm}^{-1}$, and $740-1446 \mathrm{~cm}^{-1}$ was used for prediction of NSO in binary mixtures with $\mathrm{R}^{2}$ of 0.9984 and root mean square error of calibration (RMSEC) of $1.34 \% \mathrm{v} / \mathrm{v}$. In addition, NSO mixed with SO was determined using the first derivative FTIR spectra at combined wavenumbers of 2985-3024 $\mathrm{cm}^{-1}$ and $752-1755 \mathrm{~cm}^{-1}$ with $\mathrm{R}^{2}$ and RMSEC values of 0.9970 and $0.47 \% \mathrm{v} / \mathrm{v}$, respectively. The mode of second derivative FTIR spectra at combined wavenumbers of $2977-3028 \mathrm{~cm}^{-1}, 1666-1739$ $\mathrm{cm}^{-1}$, and $740-1446 \mathrm{~cm}^{-1}$ was used for quantification of NSO in ternary systems with $\mathrm{CO}$ and SO with $\mathrm{R}^{2}$ and RMSEC values of 0.9993 and $0.86 \% \mathrm{v} / \mathrm{v}$, respectively. These results confirmed that FTIR spectrophotometry combined with multivariate calibration offered a reliable method for authentication of NSO.

FTIR spectroscopy in combination with PLSR also successfully used for quantitative analysis of NSO in binary mixture with sunflower oil (SFO) and walnut oil (WO) in the systems of NSO-WO, NSO-WO and NSOSFO-WO. PLSR using normal spectra at whole wavenumbers of mid-infrared $\left(4000-650 \mathrm{~cm}^{-1}\right)$ was 
selected for quantification of NSO in NSO-WO, NSOWO and NSO-SFO-WO with $\mathrm{R}^{2}$ of $>0.99$ in calibration and prediction or validation models. Classification of NSO and NSO adulterated with SFO and WO was successfully done using chemometrics of principal component analysis (PCA) using absorbances as wavenumbers region of $3009-721 \mathrm{~cm}^{-1}$. Based on score plot of first principle component (PC1) and second principal components (PC2), pure NSO can be clearly separated from NSO adulterated with SFO and WO (Rohman et al., 2015). For authentication purpose, the presence of grapeseed oil (GSO) in NSO as adulterant was also analyzed using FTIR spectroscopy. PLSR at combined wavenumbers of 1114-1074, 1734-1382 and $3005-3030 \mathrm{~cm}^{-1}$ could be successfully used for quantification of GSO in NSO with $\mathrm{R}^{2}$ for the relationship between actual (x-axis) and FTIR predicted (y-axis) values are 0.981 . The errors in cross-validation and in prediction are $2.34 \%(\mathrm{v} / \mathrm{v})$ and $2.37 \%(\mathrm{v} / \mathrm{v})$, respectively.

FTIR spectroscopy using attenuated total reflectance (ATR-FTIR) has also used for quantitative analysis of NSO from alginate beads. ATR-FTIR method has been developed for quantification of encapsulation efficiency of NSO by applying Beer-Lambert law after selecting the combinations of wavenumbers. The developed method was valid with linearity in the range of $25-300 \mathrm{mg} / \mathrm{mL}$ with $\mathrm{R}^{2}=0.998$, precision as expressed with relative standard deviation (RSD) of $8.4 \%$, limit of detection of $0.28 \mathrm{mg} \mathrm{NSO} / \mathrm{mL}$ and limit of quantification of $0.87 \mathrm{mg}$ $\mathrm{NSO} / \mathrm{mL}$ (Khismatrao et al., 2018).

\section{Antioxidant activities of Nigella sativa oil}

Many beneficial activities of NSO in human health and mechanisms of action has been reported in relation to NSO which include antioxidant either in vitro or in vivo, immunomodulatory, anti-inflammatory, antibacterial, antiviral, antifungi, and antiparasitic activities (Abd El-Hack et al., 2016). In this review, the antioxidant activities of NSO were highlighted either in vitro or in vivo.

Free radicals can cause several degenerative diseases due to an imbalance between oxidant (free radicals) and antioxidants in the human body. Reactive oxygen species and reactive nitrogen species (ROS/RNS) are believed to cause and aggravate several degenerative diseases in human such as diabetes mellitus and cancer (Kale et al., 2015), therefore human body needs endogenous and exogenous antioxidants. Any substances present in low concentrations coming from natural or synthetic sources with the ability to delay or inhibit free radical reaction can be considered antioxidants (NurAlam et al., 2013).
Several tests have been used for evaluation of antioxidant activities in vitro and in vivo. In vitro, the antioxidant activities of plant samples were assessed by: (1) radical scavenging methods using several radicals namely 2,2'-diphenyl-1-picrylhydrazil (DPPH), 2,2'azinobis-(3-ethylbenzothiazoline-6-sulfonic acid) $\left(\mathrm{ABTS}^{\circ+}\right)$, hydrogen, nitric oxide, and peroxy-nitrite radicals, (2) reducing power including ferric reducing antioxidant power (FRAP), ferric-thiocyanate, phosphomolybdenum method, cupric ion reducing antioxidant capacities, (3) metal chelating power, (4) lipid peroxide inhibition using beta-carotene bleaching linoleic-ferric-thiocyanate, and thiobarbituric acid (TBA) methods (Antolovich et al., 2002; Schaich et al., 2015). Evaluation of antioxidant in vivo typically was performed using animal models in which the animals were administrated with tested samples at certain doses along with positive controls such as tocopherols and phenolic compounds (Moniruzzaman et al., 2015). After the specified time of treatment period, the animals were sacrificed, and the tissue or blood was exploited for in vivo antioxidant assay and antioxidant enzymes were measured. Several enzymes used as an antioxidant measure are catalase, glutathione reductase, superoxide dismutase, glutathione peroxidase, gamma-glutamyl transpeptidase activity, and glutathione S-transferase. Besides, glutathione levels and lipid peroxidation were also used as indicative of antioxidant activity in vivo (NurAlam et al., 2013).

Mohammed et al. (2016) have extracted NSO using supercritical fluid extraction (SFE) and cold press (CP) and evaluated its antioxidant activities using DPPH radical scavenging assay, ferric reducing activity power (FRAP) and total phenolics contents. Using DPPH assay, NSO extracted using SFE had higher antioxidant activity that extracted using $\mathrm{CP}$ with $\mathrm{IC}_{50}$ values of $1.58 \mathrm{mg} / \mathrm{mL}$ and $2.30 \mathrm{mg} / \mathrm{mL}$, respectively. FRAP values of NSO extracted from SFE and CP were $538.67 \mathrm{mmol} / 100 \mathrm{~mL}$ and $329.00 \mathrm{mmol} / 100 \mathrm{~mL}$, respectively. These antioxidant activities were correlated with the phenolics contents in which SFE-extracted NSO have phenolics of $160.51 \mathrm{mg} / 100 \mathrm{~mL}$ gallic acid equivalent (GAE), higher than CP-extracted NSO with phenolics contents of 94.40 $\mathrm{mg} / 100 \mathrm{~mL}$ GAE. Kiralan et al. (2014) have compared NSOs extracted from three methods (Soxhlet extraction using hexane, microwave extraction, and cold press) for its ability to inhibit DPPH radicals. The highest inhibition rate of DPPH radicals was observed for coldpressed NSO (78.4\%), over Soxhlet extraction (65.58\%) and NSO-microwave assisted extraction (61.7\%). This inhibition was in line with the total phenolics contents in NSOs, i.e. $36.05 \%, 15.19 \%$ and $21.44 \%$ for NSO-cold press, NSO-extracted microwave, and NSO-Soxhlet extraction. 
NSOs differed in its oxidative stability as indicated by OSI. The lowest OSI value was $76.73 \pm 2.45 \mathrm{hrs}$, while the highest one was $157.58 \pm 0.00$. The greater OSI value, the longer shelf life of edible fats and oils. As a comparison, OSI values of corn oil and soybean oil were about 66 and $47 \mathrm{~h}$ respectively, determined using the same conditions as NSO (Lutterodt et al., 2010). These results indicated press cold extracted-NSO have good oxidative stability. All NSOs exhibited DPPH radical scavenging capacity by quenching of 76.4-83.5 $\mu \mathrm{mol}$ from initial $100 \mu \mathrm{mol} \mathrm{DPPH}$ radicals in the reaction mixtures. This activity was supported by ESR study in which cold-pressed NSOs contained natural antioxidants of phenolics compounds ranging 1.02-1.40 $\mathrm{mg} \mathrm{GAE} / \mathrm{g}$ oil and also contained thymoquinone of 3.48$8.73 \mathrm{mg} / \mathrm{g}$ (Parry et al., 2005).

Mraihi et al. (2013) have compared antioxidant activity of NSO using DPPH radical scavenging method from Tunisia (NSO-T), Libya (NSO-L) and Saudi Arabia (NSO-S) extracted using Soxhlet with hexane as solvent. NSO-S revealed the higher antioxidant activity than NST and NSL with $\mathrm{IC}_{50}$ of $0.422,0.507$ and $0.528 \mu \mathrm{g} / \mu \mathrm{L}$, respectively. The lower the $\mathrm{IC}_{50}$ value, the higher the antioxidant activity of NSO. Haron et al.(2014) reported antioxidant activities of 5 different bats NSO from Malaysia, Sudan and Iran using DPPH radical scavenging and $\beta$-carotene bleaching. Using DPPH assay, NSO from Iran showed the highest DPPH radical scavenging activity with $\mathrm{IC}_{50}$ of $1.49 \mathrm{mg} / \mathrm{mL}$, while NSO from Sudan has $\mathrm{IC}_{50}$ of $4.48 \mathrm{mg} / \mathrm{mL}$. Using $\beta$-carotenelinoleic acid assay, the highest inhibition activity was observed in NSO from Kelantan Malaysia with inhibition activity of $97.86 \pm 0.24 \%$.

NSO has been evaluated for its capacity as an antioxidant in vivo using forty-two patients with rheumatoid arthritis (RA). The patients were divided into 2 groups, namely patients treated with 2 capsules containing $500 \mathrm{mg}$ NSO and those treated with placebo. Some inflammatory and antioxidant parameters namely serum interleukin (IL)-10, serum antioxidant total capacity, and antioxidant enzymes (superoxide dismutase and catalase) were measured at baseline and the end of the trial. The results showed that levels of IL-10 in patients treated with NSO were increased, while serum malonaldehyde and nitric oxides were decreased compared to baseline. However, there is no significant difference $(\mathrm{P}>0.05)$ in the levels of superoxide dismutase, catalase, and total antioxidant serum capacity either between-within or before-after intervention of NSO. This study indicated that NSO could reduce oxidative stress in patients with rheumatoid arthritis, and NSO may be used as adjunct therapy in RA patients (Hadi et al., 2016).
The effects of NSO concurrent with a low-calorie diet on lipid peroxidation and oxidative status in obese women has been investigated by Namazi et al. (2015) by investigating SOD and other antioxidant parameters in vivo. Participants (50 women) were divided randomly into 25 participants who treated with intervention $(3 \mathrm{~g} /$ day NSO) and 25 participants who received placebo $(3 \mathrm{~g} /$ day) for 8 weeks. SOD in treated participants with NSO was increased significantly compared to those treated with placebo, however, there were no significant differences in lipid peroxidation, glutathione peroxidase, and total antioxidant capacity concentrations.

NSO was also investigated for its activity in inhibiting lipid peroxidation on rats treated with tartrazine. Tartrazine was known to decrease total protein, antioxidants and high-density lipoproteins. The results showed that NSO con protects male rats via inhibition of lipid peroxidation against the adverse effects resulted from the administration of tartrazine (AlSeeni et al., 2018). NSO given to guinea-pigs also increased the levels of MDA, SOD activity and GSH (Saleh et al., 2012). Ilhan et al. (2005) reported that NSO remarkably raised the GSH levels and depressed the MDA level in rats. The thymoquinone present in volatile oil of NSO had a protective effect on acute gastric damage in the rats (Arslan et al., 2005). These findings have reported that the whole herbal plants, cold pressed or essential oil, extracts and their active molecules, especially, thymoquinone, possess antioxidants, supporting the common folk perception of black cumin as antioxidant and anti-inflammatory factors (Amin and Hosseinzadeh, 2016).

\section{Conclusion}

Nigella sativa oil is excellent oil to be used in nutritional and pharmaceutical application due to some active components present such as tocopherol, phenolics compounds, and thymoquinone believed to be responsible for beneficial effects to human health including antioxidant. Some physico-chemical analyses indicated that NSO from different regions has bit difference make a need to standardize NSO. Some instrumental analysis of FTIR spectroscopy could be used for authentication analysis of NSO to assure its quality and authenticity.

\section{Conflict of Interest}

We declare that we have no conflict of interest.

\section{Acknowledgement}

The authors are grateful to the Ministry of Research and Higher Education, Republic of Indonesia and 
Directorate of Research Universitas Gadjah Mada, Yogyakarta Indonesia for financial support during preparing this review article through scheme World Class Research 2019 with contract number of 1973/ UN1.DITLIT/DIT-LIT/LT/2019.

\section{References}

Abd El-Hack, M.E., Alagawany, M., Farag, M.R., Tiwari, R., Karthik, K. and Dhama, K. (2016). Nutritional, healthical and therapeutic efficacy of black cumin (Nigella sativa) in animals, poultry and humans. International Journal of Pharmacology, 12 (3), 232-248. https://doi.org/10.3923/ ijp.2016.232.248

Adamu, H.M., Ekanem, E.O. and Bulama, S. (2010). Identification of essential oil components from Nigella sativa seed by gas chromatography-mass spectroscopy. Pakistan Journal of Nutrition, 9(10), 966-967. https://doi.org/10.3923/pjn.2010.966.967

Ahmad, A., Husain, A., Mujeeb, M., Khan, S.A., Najmi, A.K., Siddique, N.A., Damanhouri, Z.A. and Anwar, F. (2013). A review on therapeutic potential of Nigella sativa: A miracle herb. Asian Pacific Journal of Tropical Medicine, 3(5), 337-352. https:// doi.org/10.1016/s2221-1691(13)60075-1

Al-Seeni, M.N.,El Rabey, H.A., Ahmad, H.A. and Zamazami, M.A. (2018). Nigella sativa oil protects against tartrazine toxicity in male rats. Toxicology Reports, 5, 146-55. https://doi.org/10.1016/ j.toxrep.2017.12.022.

Amin, B. and Hosseinzadeh, H. (2016). Black cumin (Nigella sativa) and its active constituent, thymoquinone: An overview on the analgesic and anti-inflammatory effects. Planta Medica, 82(01/02), 8-16. https://doi.org/10.1055/s-0035-1557838

Ansari, Z.M., Nasiruddin, M., Khan, R.A. and Haque, S.F. (2016). Evaluation of efficacy and safety of Nigella sativa oil supplementation in patients of chronic kidney disease. Asian Journal of Pharmaceutical and Clinical Research, 9, 107-110.

Antolovich, M., Prenzler, P.D., Patsalides, E., McDonald, S. and Robards, K. (2002). Methods for testing antioxidant activity. Analyst, 127(1), 183198. https://doi.org/10.1039/b009171p

Argon, Z.U. and Gokyer, A. (2016). Determination of Physicochemical Properties of Nigella sativa Seed Oil from Balıkesir Region, Turkey. Chemical Process and Engineering Research, 41, 43-46.

Arslan, S.O., Gelir, E., Armutcu, F., Coskun, O., Gurel, A., Sayan, H. and Celik, I.L. (2005). The protective effect of thymoquinone on ethanol-induced acute gastric damage in the rat. Nutrition Research, 25(7),
673-680.

https://doi.org/10.1016/

j.nutres.2005.06.004

Cheikh-Rouhou, S., Besbes, S., Hentati, B., Blecker, C., Deroanne, C. and Attia, H. (2007). Nigella sativa L. Chemical composition and phytochemical characteristics of lipid fraction. Food Chemistry, 101 (2), 673-681. https://doi.org/10.1016/ j.foodchem.2006.02.022

D'Antuono, L.F., Moretti, F. and Lovato, A.F.S. (2002). Seed yield, yield components, oil content and essential oil content and composition of Nigella sativa L. and Nigella damascena L. Industrial Crops Products, 15(1), 59-69. https://doi.org/10.1016/ s0926-6690(01)00096-6

Gharby, S., Harhar, H., Guillaume, D., Roudani, A., Boulbaroud, S., Ibrahimi, M., Ahmad, M., Sultana, S., Hadda, T.B., Chafchaouni-Moussaoui, I. and Charrouf, Z. (2015). Chemical investigation of Nigella sativa L. seed oil produced in Morocco. Journal of Saudi Society of Agricultural Sciences, 14 (2), 172-177. https://doi.org/10.1016/ j.jssas.2013.12.001

Hadi, V., Kheirouri, S., Alizadeh, M., Khabbazi, A. and Hosseini, H. (2016). Effects of Nigella sativa oil extract on inflammatory cytokine response and oxidative stress status in patients with rheumatoid arthritis: a randomized, double-blind, placebocontrolled clinical trial. Avicenna Journal of Phytomedicine, 6(1), 34-43.

Haron, H., Grace-Lynn, C. and Shahar, S. (2014). Comparison of Physicochemical Analysis and Antioxidant Activities of Nigella sativa Seeds and Oils from Yemen, Iran and Malaysia. Sains Malaysiana, 43, 535-542.

Ilhan, A., Gurel, A., Armutcu, F., Kamisli, S. and Iraz, M. (2005). Antiepileptogenic and antioxidant effects of Nigella sativa oil against pentylenetetrazoleinduced kindling in mice. Neuropharmacology, 49 (4), 456-464. https://doi.org/10.1016/ j.neuropharm.2005.04.004

Kale, M.A., Bindu, S.M. and Khadkikar, P. (2015). Role of antioxidants and nutrition in oxidative stress: a review. International Journal of Applied Pharmaceutics, 7(1), 1-4.

Khan, A.M. (1999). Chemical composition and medicinal properties of Nigella sativa Linn. InflammoPharmacology, 7(1), 15-35. https:// doi.org/10.1007/s10787-999-0023-y

Khismatrao, A., Bhairy, S. and Hirlekar, R. (2018). Development and validation of RP-HPLC method for simultaneous estimation of curcumin and piperine. International Journal of Applied Pharmaceutics, 10(5), 43-48. https:// 
doi.org/10.22159/ijap.2018v10i5.21140

Khoddami, A., Ghazali, H.M., Yassoralipour, A., Ramakrishnan, Y. and Ganjloo, A. (2011). Physicochemical Characteristics of Nigella Seed (Nigella sativa L.) Oil as Affected by Different Extraction Methods. Journal of the American Oil Chemists' Society, 88(4), 533-540. https:// doi.org/10.1007/s11746-010-1687-6

Kiralan, M., Ozkan, G., Bayrak, A. and Ramadan, M.F. (2014). Physicochemical properties and stability of black cumin (Nigella sativa) seed oil as affected by different extraction methods. Industrial and Crops Products, 57, 52-58. https://doi.org/10.1016/ j.indcrop.2014.03.026

Lutterodt, H., Luther, M., Slavin, M., Yin, J.J., Parry, J., Gao, J.M. and Yu, L. (2010). Fatty acid profile, thymoquinone content, oxidative stability, and antioxidant properties of cold-pressed black cumin seed oils. LWT - Food Science and Technology, 43 (9), 1409-1413. https://doi.org/10.1016/ j.lwt.2010.04.009

Mohammed, N.K., Manap, M.Y.A., Tan, C.P., Muhialdin, B.J., Alhelli, A.M. and Hussin, A.S.M. (2016). The Effects of Different Extraction Methods on Antioxidant Properties, Chemical Composition, and Thermal Behavior of Black Seed (Nigella sativa L.) Oil. Evidence-Based Complementary and Alternative Medicine, 2016, 6273817. http:// dx.doi.org/10.1155/2016/6273817

Moniruzzaman, M., Khalil, M.I., Sulaiman, S.A. and Gan, S.H. (2015). Advances in the Analytical Methods for Determining the Antioxidant Properties of Honey: A Review. African Journal of Traditional and Complement Alternative Medicine, 9, 36-42. http://dx.doi.org/10.4314/ajtcam.v9i1.5

Mraihi, F., Journi, M., Chérif, J.K. and Trabelsi-Ayadi, M. (2013). Characterization of three Nigella Sativa L. Crude Oil Species, Measures of their Antioxidant Activity by DPPH. Journal of Biology and Active Products Nature, 3(3), 208-215. https:// doi.org/10.1080/22297928.2013.797630

Namazi, N., Mahdavi, R., Alizadeh M. and Farajnia, S. (2015). Oxidative Stress Responses to Nigella sativa Oil Concurrent with a Low-Calorie Diet in Obese Women: A Randomized, Double-Blind Controlled Clinical Trial. Phytotherapy Research, 29(11), 17221728. https://doi.org/10.1002/ptr.5417

NurAlam, M., Bristi, N.J. and Rafiquzzam, M. (2013). Review on in vivo and in vitro methods evaluation of antioxidant activity. Saudi Pharmaceutical Journal, 21(2), 143-152. http://dx.doi.org/10.1016/ j.jsps.2012.05.002
Nurrulhidayah, A.F., Che Man, Y.B., Al-Kahtani, H.A. and Rohman, A. (2011). Application of FTIR spectroscopy coupled with chemometrics for authentication of Nigella sativa seed oil. Spectroscopy, 25(5), 243-250. https:// doi.org/10.1155/2011/470986

Parry, J.W., Su, L., Luther, M., Zhou, K., Yurawecz, M.P. and Whitaker, P. (2005). Fatty acid composition and antioxidant properties of coldpressed marionberry, boysenberry, red raspberry, and blueberry seed oils. Journal of Agricultural and Food Chemistry, 53(3), 566-73. https:// doi.org/10.1021/jf048615t

Ramadan, M.F., Kinni, S.G., Seshagiri, M. and Mörsel, J.T. (2010). Fat-soluble bioactives, fatty acid profile and radical scavenging activity of Semecarpus anacardium seed oil. Journal of the American Oil Chemists' Society, 87(8), 885-894. https:// doi.org/10.1007/s11746-010-1567-0

Rohman, A. and Ariani, R. (2013). Authentication of Nigella sativa Seed Oil in Binary and Ternary Mixtures with Corn Oil and Soybean Oil Using FTIR Spectroscopy Coupled with Partial Least Square. The Scientific World Journal: Analytical Chemistry, 2013, 740142. http:// dx.doi.org/10.1155/2013/740142.

Rohman, A., Wibowo, D., Sudjadi, Lukitaningsih, E. and Rosman, A.S. (2015). Use of Fourier Transform Infrared Spectroscopy in Combination with Partial Least Square for Authentication of Black Seed Oil. International Journal of Food Properties, 18(4), 775 -784. https://doi.org/10.1080/10942912.2014.908207

Saleh, S., Eldenshary, E.M.S., Mahran, L. and Salah, N. (2012). Nigella sativa (Black seed) oil: Antiinflammatory and antioxidant effects in experimental models of allergic asthma. $1^{\text {st }}$ USIM International Conference on Medicine and Health (ICMH2012), 19-20 May 2012. Kuala Lumpur, Malaysia. [Presentation Slides]. https:// doi.org/10.13140/2.1.3966.5927.

Schaich, K.M. and Xie, X.T.J. (2015). Reprint of "Hurdles and pitfalls in measuring antioxidant efficacy: A critical evaluation of ABTS, DPPH, and ORAC assays. Journal of Functional Foods, 18(B), 782-796. https://doi.org/10.1016/j.jff.2015.01.043

Sultana, S., Asif, H.M., Akhtar, N., Iqbal, A., Nazar, H. and Ur Rehman, R. (2015). Nigella sativa: Monograph. Journal of Pharmacognosy and Phytochemistry, 4(4), 103-106. 